\title{
CrimRxiv
}

\section{Transnational Organized Crime:Analyses of a Global Challenge to Democracy}

Heinrich-Böll-Stiftung, Regine Schönenberg, Annette von Schönfeld

Published on: Mar 17, 2014

DOI: 10.21428/cb6ab371.67b10530

License: Creative Commons Attribution 4.0 International License (CC-BY 4.0). 
